\title{
Human Rights as a Resource - The Nigerian Experience
}

\author{
By M. Adekunle Owoade
}

\section{Introduction}

Nigeria is a multi-ethnic Federal Republic with a population of nearly 100 million and an area of about 357,000 square miles. The three principal linguistic groups correspond to the country's major ethnic groups which are the Hausa, Igbo and Yoruba. In addition to a distinct language, each group has its own customs, religions and traditional political organizations. The country secured independence in 1960 and by 1963 acquired a Republican status still under the parliamentary model Constitution. It was under military rule from 1966 to 1979 and from 1984 to date. It had a short civilian interregnum from 1979 to 1983 with its first taste of presidential system under the leadership of Shehu Shagari. Consequently since independence, it has had 20 years of military rule as against 10 years of civilian administration.

It is with this chequered historico-political background of a multi-ethnic, multi-linguistic indeed 'multi-national' state that one examines the dimensions of the problems posed by human rights. As a term in political rhetoric, the concept of human rights is beset by a number of connotation 1 . Generally, however, it has been suggested that respect for fundamental human rights in Africa has not, on the whole, been very high because of the continent's historical and cultural background. Human rights thrive best in free and stable societies that are closely knit through culture, language and religion. The failure of the new regimes to bring about the promised new life, the prevalence of corruption and continuation of misery attracted military coups which, in many cases, were welcomed initially. The military, in turn, failed to provide the answers to the endemic problems - unemployment and poor social services. Renewed opposition came from the civilians and from military ranks. Vested with the virtual monopoly of power, the reaction of military governments to opposition was more brutal and punctuated with greater denial of human rights to opposition elements. The military usurpation of power, especially when prolonged, became an important element of indiscipline in society. 2

1 At least three categories of humane rights are clearly indentifiable. The first are the purely political and civil rights, the second are the socio-economic and the third are group or solidarity rights.

2 Umozurike, U.O., 'The Present State of Human Rights in Africa', Cal.L.J., 1986, p. 62. 


\section{Equality of Rights and Obligations}

Equality before the law is a concept concerned, not primarily to define private relationship of citizens inter se, but to ensure that they are treated in the same way by the state. Under the Constitution of Nigeria, every person has the fundamental rights to life, dignity of the human person, personal liberty, fair hearing, private and family life, freedom of thought, conscience and religion, freedom of expression and the press, peaceful assembly and association, freedom of movement, and property; the state is enjoined not to violate or contravene them, contravention of them being redressible in the courts by appropriate remedies. The emphasis is on the word 'every' which means all persons equally, regardless of their station in life or standing in society, whether poor or rich, powerful or inconsequential, of lowly or noble birth, etc. Equality also characterizes even the distinctly political right to vote at the election of those to govern. As with rights, the obligations of membership of the state are equal as between all citizens; all have the same or equal duty of obedience to the laws of the country, and none is above law. This requires that laws be made for all equally, and that duty to obey them be the same or equal for all, with no exemption for of ficials to act outside them. ${ }^{3}$ It must be observed that the fundamental human rights provisions as contained in chapter IV of the Nigerian Constitution 4 are entrenched and they take a natural pride of place having regard to the provision relating to the supremacy of the Constitution in Section 1(1) of the same document. Clearly then, the charter contains a constitutional structure that supports the individualistic, liberal conception of democratic society epitomized by theorists such as John Stuart Mill. Ironically perhaps, the philosophy behind the charter might well be one of its major hindrances. The Nigerian charter, like those of most civilized democracies is legalistic, positivistic and individualistic. Unfortunately but understandably, this hopeful characteristic of the charter does not mesh well with its under-utility and indeed societal needs for its practical resourcefulness. Consequently, the significance of the human rights provisions within a broad socio-economic wave-length becomes incredibly undermined. Neither is it the case that a human and politically stable social order can be easily achieved within the limiting factors of the constitutional provisions themselves. What, for example, is the meaning of a right to life when, on the one hand, life, limb and property are not beyond the growing menace of armed robbers and hired assessins or, on the other hand, by the continuous availability of the death penalty to an increasing number of offences and offenders. 5 The propositions sound inconsistent but it is left for society to

3 Nwabueze, B.O., 'Equality before the Law', in: Ajomo, M.A., ed.: Fundamentals of Nigerian Law, N.I.A.L.S. Law Series No. 2, 1989, Lagos, pp. 39-41.

4 The Constitution of the Federal Republic of Nigeria 1979 hereinafter referred to as the 'Constitution'.

5 In Nigeria, the death penalty is available for the offences of murder, treason, instigating invasion of Nigeria and treachery. In 1970 it was extended to armed robbery and in 1974 to offences of kidnapping and lynching. Luckily, however, the upward trend introduced by the Buhari regime in 
resolve the dialectic. Between 1981 and 1985, 6,794 cases of armed robbery and related offences were reported to the police; an in 3,830 of them, prosecution was actually instituted. In the same period, 90,393 cases of burglary and related of fences were reported and 41,411 were prosecuted. 6 The constitutional right to the dignity of the human person can hardly be realized within the framework of our vicious circle of poverty - with 30 billion dollars external debt and the difficulty of managing a state of hyper-inflation. The socio-economic conditions are characterized by unemployment, poverty, poor social and health conditions and, indeed, the indignity of the human person.

Personal liberty is undermined by the incessant abuse of power by uninformed men, unlawful detentions and illegal raids, while the practical utility of the fair hearing provisions become illusory, with court congestions and delays in the admininstration of justice, inadequate manpower and rising legal fees, usually beyond the reach of the average man in society. In this respect, though the Legal Aid Scheme is welcomed, it is still limited in scope and coverage for any substantial effectiveness. By the Legal Aid Decree No. 56 of 197 as amended (1986) only a person whose income does not exceed $\$ 1,500.00$ per annum can benefit. This covers only civil cases relating to claims in respect of personal accidents or for offences such as murder, manslaughter, maliciously inflicting grievous harm and the aiding and abetting of such offences.

Freedom of movement is hampered by discriminatory and differential treatment, consequent on the malaise of ethnicism and station. It seems there is the need to redefine and rethink the concept of rights to be able to accomodate greater individual and group interests, as well as the unflinching commitment of the state to its own obligations. ${ }^{7}$

\section{Fundamental Objectives and Directive Principals of State Policy}

The nearest to the above suggestion is the Fundamental Objectives and Directive Principles of State Policy as contained, for the first time even, in the 1979 Constitution. The provisions concern not only the philosophical or ideological justification of the Nigerian state

but also the direction and source of control of the Nigerian economy. Sections 13-22 of the

particular by the Miscellaneous Offences Degree of 1984 was arrested by the Babangida administration.

6 The figures are calculations derived from the Annual Abstract of Statitistics 1986, Federal Office of Statistics, Lagos.

7 "If the State is the product of a social contract, then, no citizen should rank higher or lower nor count more or less than any other citizen in relation to it (that is, the State). In this view, the State is an organization in which the relationship of all members to it should be on equal terms whether it pertains to rights, obligations, the security of lives and property, the administration of justice and ... the exercise of legislative and executive power," - Nwabueze, B.O., op. cit., p. 39. 
Constitution laid down broad guidelines by which the Federal Republic shall be ruled. These include Political, Economic, Social, Educational as well as Foreign Policy Objectives. It also includes Directives on Nigerian Culture, Obligations of the Mass Media and National Ethics.

As a prelude to these lofty ideals in the Constitution, the Report of the Constitution Drafting Committee had this to say8:

"Government in Nigeria, as indeed in other developing countries has tended to be preoccupied with power and its material perquisites. Given the country's conditions of under-development power of fers the opportunity of a lifetime to rise above the general poverty and squalor that pervades the entire society. It provides a rare opportunity to acquire wealth and prestige to be able to distribute benefits in the form of jobs, contracts, scholarships and gifts of money and so on to one's relatives, and political allies. Such is the preoccupation with power and its material benefits that political ideologies as to how society can be organized and ruled to the best advantage of all hardly enter into calculation."

And it continues as follows:

"Perhaps the Constitution is in part to blame for this. The Constitution in Commonwealth Africa speaks only in terms of power and rights, but never of duties. The latter are taken for granted. The Constitution assumes that those who wield the power of the State will be conscious of, and responsive to, its obligations and responsibilities. And so it says nothing of the duties of the government toward its subjects. Our experience has shown this to be a wrong approach to Constitution making. As a charter of government and the fundamental law of the land, the Constitution should make it clear that powers are betowed upon the organs and institutions of government, not for the personal aggrandizement of those who wield them from time to time, but for the welfare and advancement of the society as a whole; it should therefore cast on the state definite duties towards its objects."

Section 13 of the charter enjoins all organs of government to conform to, observe and apply the provisions relating to the Fundamental Objectives, and Section 14 specifically declares inter alia that Sovereignty belongs to the people of Nigeria from whom government through this Constitution derives all its powers and authority.

Of particular significance is Section 17 which deals with social objectives.

8 Report of the Constitution Drafting Committee, Vol. II (1976), p. 35. 
"7 -(1) The State social order is founded on ideals of Freedom, Equality and Justice.

(2) In furtherance of the social order

(a) every citizen shall have equality of rights, obligations and opportunities before the law;

(b) the sanctity of the human person shall be recognized and human dignity shall be maintained and enhanced;

(c) govemmental actions shall be humane;

(d) exploitation of human or natural resources in any form whatsoever for reasons other than the good of the community shall be prevented; and

(e) the independence, impartiality and integrity of courts of law, and easy accessibility thereto shall be secured and maintained.

(3) The State shall direct its policy towards ensuring that

(a) all citizens without discrimination on any ground whatsoever have the opportunity for securing adequate means of livelihood as well as adequate opportunities to secure suitable employment;

(b) conditions of work are just and humane, and that there are adequate facilities for leisure and for social, religious and cultural life;

(c) the health, safety and welfare of all persons in employment are safeguarded and not endangered or abused;

(d) there are adequate medical and health facilities for all persons;

(e) there is equal pay for equal work without discrimination on account of sex, or on any other ground whatsoever;

(f) children, young persons and the aged are protected against any exploitation whatsoever, and against moral and material neglect; and

(g) provision is made for public assistance in deserving cases or other conditions of need."

To the extent that successive governments in Nigeria have always had economic, social, political, educational and cultural objectives embodied in the various National Development Plans, the Fundamental Objectives provisions are neither exactly nor entirely novel. Common to these Development Plans is the goal of distributing the benefits of development to all strata of the population with a view to removing the inequalities that have predominantly existed between these strata - in a continuous desire for a just and egalitarian society. 9

Regrettably, despite this awareness, and its eventual fulfilment by the provisions relating to Fundamental Objectives in the Constitution, Section 6(6)(c) of the Constitution says that the said provisions shall not be justiciable. The non-justiciability of the provisions could be

9 See e.g. Second National Development Plan 1970-74, p. 33 and Third National Development Plan 1975-80, p. 29, Lagos, Federal Ministry of Information. 
explained on the ground that if it were otherwise, there could be multiplicity of frivolous and vexatious litigations. Yet this objection could be accomodated with some provisions for enforcement of the rules. One way out is to ask the Executive to report to the Assemblies, annually on how far the provisions had been complied with. Secondly, to reduce frivolous actions, there should be rights vested in the Assembly members only as the acknowledged representatives of the people to institute legal actions in the nature of declarations on the provisions of the Fundamental Objectives and Directive Principles of State Policy. It must be mentioned that the Constitutional Drafting Committee (C.D.C.) had somewhat similar thoughts in the Draft submitted on the Directive Principles of State Policy:

\begin{abstract}
"We have gone further than India and Pakistan in making the principles justiciable to a limited extent. They have been made justiciable only by means of declaratory actions, and even this is qualified by the provision that a declaration by the court that a law or other action is not in accordance with the Directive Principles shall not render the law or other action in question invalid to any extent whatever. However, such a declaration may be a ground for the impeachment of the appropriate functionaries." 10
\end{abstract}

Our above suggestion, unlike the idea of the Constitution Drafting Committee, involves a two-tier system of accountability and at the same time reduces the possibility of frivolous actions. Since the Executive would be obliged to report annually on the issue of conformity with the Directive Principles and a member of the House rather than any citizen can still ask for a court declaration on the issue. It seems this would go a long way to solve the problem of the conflicting views between the justiciability and non-justiciability of the provisions of chapter II of the Nigerian Constitution. 11

\title{
The Concept of Openness
}

Openness as a characteristic of society connotes the ability of individuals to leam about the activities of their govemment, to communicate to others what they have learned, and to form opinions according to the information that is available. The greater openness of govermment, the greater participation of citizens in the democratic process. Individuals can only be informed about their govemment's behaviour if they have access to information about its functions. Also, a govemment will only be accountable to a citizenry that can scrutinize its actions. Thus, openness of govemment lies at the core of a democratic society.

10 Report of the Constitution Drafting Cornmittee, op. cit. p. 40.

11 See generally Chapter I. Ofonagoro, WI. et.al. - The Great Debate - Nigerian Viewpoints on the Draft Constitution (1976/77), DAILY TIMES, Lagos. In particular, Sections 8-14 on the issue of justiciability or non-justiciability of the provisions. 
Only through access to government proceedings and information about government activities citizens can form educated opinions about the kind of government they desire, and only then they can make wise choices at the ballot box. The degree of openness in society, then, touches the ability of its members to engage in forms of conduct that are characteristically human: thinking, reasoning, creating, speaking. To confine these activities would be to constrict the growth of the human intellect. Society as a whole is the beneficiary of the exercise of these freedoms since new and often better ideas blossom from them. 12 Although this vision of democratic society is by no means axiomatic or immutable, it has been given constitutional recognition in the Nigerian charter. Consequently, everyone has the following fundamental freedoms: (a) freedom of conscience and religion; (b) freedom of thought, belief, opinion and expression, including freedom of the press; (c) freedom of peaceful assembly and (d) freedom of association.

These freedoms taken together, resemble a "system of freedom of expression" to use Emerson's terms, or a blueprint for an open society. Emerson describes the integration of this system within a democratic society as follows 13 :

\begin{abstract}
"A system of freedom of expression, operating in a modern democratic society, is a complex mechanism. At its core is a group of rights assured to individual members of the society. This set of rights, which makes up our present-day concept of free expression, includes the right to form and hold beliefs and opinions on any subject, and to communicate ideas, opinions, and information through any medium - in speech, writing, music, art, or in other ways. To some extent it involves the right to remain silent. From the obverse side it includes the right to hear the views of others and to listen to their versionn of the facts. It encompasses the right to inquire and, to a degree, the right of access to information. As a necessary corollary, it embraces the right to assemble and to form associations, that is, to combine with others in joint expression."
\end{abstract}

Alexander Meiklejohn, one of the foremost proponents of the view that freedom of the press and freedom of expression are essential to the democratic process, believed that the over riding purpose of the first Amendment of the American Bill of Rights, which protects freedom of speech and of the press, was to safeguard the democratic system of government protected and created by the Constitution. 14

Public and Media Access to the Criminal Process, working paper 56, Law Reform Commission of Canada, 1987, pp. 5-8.

13 Emerson, T.I., The System of Freedorn of Expression, New York: Random House 1970, p. 3.

14 Meiklejohn, A., Free Speech and Its Relation to Self-Govemment, New York: Harper \& Bros. 1948, p. 88. 
Perhaps the most influential writer on this subject was John Stuart Mill. Mill departed from the prevailing nineteenth century utilitarian concept of democracy - the strict adherence to majority rule - by arguing that free expression was so crucial to democracy that it must prevail even over the contrary wishes of the majority. 15

Broadly speaking, Sections $35-38$ of the Nigerian Constitution deal with the various important aspects of the concept of openness. Section 35 guarantees the right to freedom of thought, conscience and religion; and, to all intent and purposes, the Section undoubtedly corroborates the secularity of the Nigerian state. The freedom of thought, conscience and religion are expressed in wide terms and include the right to change one's religion or political belief, to manifest and propagate one's religion or belief in worship, teaching, practice and observance. The guarantee goes further than the common law and forbids the imposition on a person attending an educational institution of a requirement to receive religious instructions or to participate in the religious exercises of a denomination which is not his own or which is not approved by one's parent or guardian. 16 Consequently, despite of the occasional threat to peace by issues such as the Sharia debate and the religious intolerance, and crisis surrounding the country's membership of the Organization of Islamic Conference (OIC), the constitutional provision continues to be a potent weapon in the maintenance of social order and political stability. It is noteworthy that sub-section 4 of section 35 qualifies the provision by banning "secret societies ... whose activities are to the detriment of the legitimate expectation of those who are not members." 17

The right to freedom of expression and the press including freedom to hold opinions and to receive and impart ideas and information without interference is now combined in Section 36. The significance of the provision lies in the fact that it does not only guarantee individual freedom of expression but also that of the media. The provision must have strengthened the Nigerian media in their increasing role to openness, since only through the media of communication can the public become aware of matters that may affect it and be exposed to a diversity of opinions. Thus, the media's freedom to gather and distribute information, ideas and opinions is intimately connected with the overall openness of society. In contrast to earlier constitutional provisions on the subject, Section 36 carefully limits the judicial discretion exercisable by the usual qualifying provision that nothing shall invalidate any law that is reasonably justifiable in a democratic society; although subsection (2) does not permit private ownership or operation of television or wireless broadcasting station for any purpose whatsoever.

15 Mill, J.S., On Liberty, 1859, reprint ed. by Elizabeth Rapaport, Indianapolis: Hackett, 1985.

16 See e.g. Akande, J., 'A Decade of Human Rights', in: Ajomo, A. (ed.): New Dimensions in Nigerian Law, N.I.A.L.A. Law Series No. 3 (1989), 101 and 106.

17 An innovation referred to by some commentators as the military's suggestion - See gen., Ojo Abiola, Constitutional Law and Military Rule in Nigeria, Evans 1987. 
Section 37 provides for the right to peaceful assembly and association, in particular he may form or belong to any political party, trade union or any other association for the protection of his interests. However, the provision does not derogate form the powers conferred by the Constitution on the Federal Electoral Commission with respect to political parties to which that Commission does not accord recognition. Also, a person elected to a legislative house as a candidate who was not sponsored by any political party shall not be entitled to join or declare himself to be a member of a political party until the next general election following his election as a candidate. 18

Section 38 deals with freedom of movement and immunity from expulsion subject however to the power of extradition for a criminal offence. Undoubtedly, in a country like Nigeria, with diverse peoples and tongues, the freedom to move in and out of the country and reside anywhere, apart from being one of the hallmarks of citizenship, is one of the ways in which unity and full integration amongst the various peoples can best be forged. Though, the particular provisions had not attracted much attention from the courts, it is hoped that a liberal interpretation as in the United States will be adopted.19

A more generalized restriction on the concept of openness could be found in the provision of Section 41 (1) which provides inter alia:

"Nothing in Sections 34, 35, 36, 37 and 38 of this Constitution shall invalidate any law that is reasonably justifiable in a democratic society

(a) in the interest of defence, public safety, public order, public morality or public health; or

(b) for the purpose of protecting the rights and freedom of other persons."

This provision has been used to justify imposition of curfew and the restriction of a person's movement to a particular place 20 and restriction on the exit of citizens to "enemy" countries. In a democratic setting, it is the courts that determine the width of the provision by pronouncing on the question of whether or not a law is reasonably justifiable.21 Under a military rule, however, the final say is with the law making body and the courts generally have no power to question the validity of laws made. 22

18 This provision is to prevent political "Carpet-crossing".

19 Apatheker v. Secretary of State, 378 U.S. 500 (1964); Kent v. Duiles, 357 U.S. 116 (1958).

20 Oba G.I. Orioge v. The Governor of Ondo State, (1982) 3 N.C.L.R. 349.

21 See e.g. Federal Minister of Internal Affairs \& Ors v. Shugaba, (1982) 3 N.C.L.R. 915.

22 See e.g. Section 5, Decree No. 1 of 1984. 


\section{Human Rights and the Judiciary Pre-1979}

From the period immediately preceding Independence to 1972, Nigeria passed through a series of political and constitutional crises which the most ardent observer of our pre-1960 political and constitutional scene would have regarded as beyond the capacity of the nation to accomodate. 23 This might well explain the climate in which the courts carry out illiberal and restrictive interpretations of the Constitution, even in such important areas as the provisions on Human Rights.

On of the earliest cases relating to the interpretation of the fundamental rights provisions in the Constitution was that of D.P.P. v. Chike Obi24, where the defence contended that Sections 50 and 51 of the Criminal Code under which the accused was charged were inconsistent with the provisions of Sections 24 of the 1963 Constitution which guaranteed freedom of speech and expression and were therefore void in accordance with Section I of the Constitution. This contention was based on the argument that "any law which punishes a person for making a statement which brings a government into discredit or ridicule or creates disaffection against the government irrespective of whether the statement is true or false and irrespective of any repercussions on public order or security is not a law which is reasonably justifiable in a democratic society.

However, the Supreme Court rejected this brilliant argument and re-affirmed the conviction of Dr. Chike Obi for the offence of sedition. 25 The court exhibited the same frame of mind in R.v. Amalgamated Press.26 In the opinion of the court, in that case, Section 24 of the Constitution of the Federation relating to fundamental rights guaranteed nothing but ordered freedom and that, that Section of the Constitution cannot be used as a licence to spread false news likely to cause fear and alarm to the public.

Section 22 of the 1963 Constitution which guarantees the right to a fair hearing, has come up for interpretation more than any other provision of the Constitution. In Gopka v.

23 Jegede, MI., 'The Supreme Court's Attitude towards some aspects of Individual Freedom and the Right to Property', in: Kasumu, A.B. (ed.), The Supreme Court of Nigeria 1956-1970, Heinemann 1977, p. 107.

24 (1961) 1 All N.L.R. 186.

25 The court came to this decision in spite of the fact that in a number of democratic countries, including England and Canada, incitement to violence is now a necessary element of the offence R. v. Bums (1886) 16 CCC 355; Boucher v. R., (1951) SCR 265 and notwithstanding that freedom of expression has been declared to be 'the touchstone of all freedoms' - General Assembly Resolution 59 (1); see The Universal Declaration of Human Rights - A Standard Achievement, UN publication, 1962, p. 9 which should be very jealously guarded by the courts. And see, generally, Ezejiofor, $G$., 'A Judicial Interpretation of Constitution: The Nigerian Experience during the First Republic' in Kasumu, A.B. (ed.), op. cit., 67 at 81.

26 (1961) 1 All N.L.R. 199. 
I.G.P. ${ }^{27}$ Mbanefo, J. (Eastern Region) held that the failure of the trial magistrate to grant the accused an adjournment in order to secure the presence of his counsel who did not know that the case was fixed for hearing on the day in question amounted to denying him the right of being defended by counsel. This was a commendable decision but the hopes raised by it were dashed by subsequent cases. in Shemfe v. C.O.P. 28 the accused appeared on the third adjoumed date and presented a telegram from his counsel requesting an adjoumment. This request was rejected by the court, which argued that since all the witnesses who were assembled from different distant towns were all present the case must go on in order to avoid inconvenience and expense. Thereafter the accused defended himself personally but was convicted and sentenced to imprisonment. He appealed to the High Court and argued that he was unfairly tried because the trial was hurriedly conducted and his counsel could not arrive to defend him. Hurley C. J. accepted that the accused was entitled to the assistance of a legal representative by virtue of Section 22(5)(c) of the Constitution. But relying on the English case of R. v. Mary Kingston29, he held that the accused failed because he was deprived of the assistance of Counsel through Counsel's own default by not appearing to defend him and by failing to explain his absence to the Court. Unfortunately the reasoning in Shemfe case was approved by the Supreme Court in Yanor \& Andiar v. The State. 30

The question in Ibeziako v. C.O.P.31 was whether section 160 of the Criminal Procedure Code, which authorizes a Magistrate to take evidence from the prosecution and frame a charge against the accused which he is of the opinion that there is ground for presuming that the accused has committed an offence, contravened section 22(4) which provides that: 'Every person who is charged with a Criminal offence shall be presumed innocent until he is proved guilty.' It was contended for the appellant that the presumption of innocence must be present when an accused person is charged and begins to stand his trial. But at the point when the Magistrate charges the accused, it was argued the presumption of innocence is already destroyed.

Surprisingly, this argument did not impress the Supreme Court. In its view the provision of Section 160 means no more than that the Magistrate is directed to formulate what seems to him to be the appropriate charge for the offence which prima facie appears to have been committed. It does not mean that the Magistrate has made up his mind that the accused is guilty.

27 (1961) 1 All N.L.R. 423.

28 (1962) N.N.L.R. 87.

2932 Cr. App. R. 183.

30 (1965) 1 All NLR 193.

31 (1963) NNLR 88. 
Another interesting case is Awolowe v. Minister of Internal Affairs. ${ }^{32}$ Section 22 (5)(c) of the Constitution provided that 'every person who is charged with a Criminal Offence shall be entitled to defend himself in person or by Legal representatives of his own choice'. The Plaintiff and others were charged with treasonable felony and conspiracy. He retained the services of an English lawyer who had a right of audience in the Nigerian Courts, but was prevented from entering the Country by the defendant in pursuance of Section 13 of the Immigration Act, which gave him absolute discretion to prevent non-Nigerians entering the Country. The Plaintiff now claimed that both this provision and the action taken thereunder infringed his Constitutional right to be defended by Legal representatives of his choice. Udoma, J., held both to be Constitutional. What the Constitution guaranteed, said the Judge, was the right of the accused to be defended by a lawyer of his choice who must be under no disability. 33

Finally the judiciary at this period exhibited the same narrow frame of mind in the exposition of the important constitutional Law concept of locus standi34.

Apart from the political climate, the conservative attitude of the then judiciary could equally be explained by the binding force of precedent, especially Common Law precedent. Furthermore, the parliamentary West-Minister model of government as well as the Constitution were relatively new; thus, the operators of the system including the judiciary were yet to evolve a culture of democracy. These, coupled with the English training of most of the judges and perhaps also some hangover of colonial mentality, must have all contributed to the timidity of the judiciary at this period.

\section{Post-1979 Judiciary}

For reasons not quite clear, it would appear that the inception of the 1979 Constitution geared up the commitment of our Courts especially the Supreme Court into a new period of legal fundamentalism with decisions that are not only relevant but also revolutionary. Besides, these are usually supported by deep philosophical expositions and jurisprudential analysis. Perhaps, this might be explained by the style of the Constitution itself i.e. a separation of powers Presidential Constitution or better still, the psychological imperatives of the American background of the document which might be an important factor in the re-

32 (1962) LLR 1777.

33 That is, a lawyer who has a right of audience in Nigerian Courts.

34 See e.g. Onyia v. Govenor in Council \& Ors, (1962) 2 All N.L.R. 174; Olawoyin v. AttomeyGeneral for Northem Nigeria, (1961) All N.L.R. 269; Dada v. University of Lagos \& Ors, (1971) U.I.L.R. 344; Ekundare v. Govemor in Council \& Anor, (1961) All N.L.R. 149; Awolowo \& Ors. v. Federal Minister of Internal Affairs \& Anor, (1962) LL.L.R. 177; Gamioba \& Ors v. Esezi \& ors, (1961) 1 A.N.L.R. 584. 
shaping of judicial attitude to emulate its American Counterpart in those complicated challenges in the development of a natural content in human rights and the legal process in general. As early as 1981, the Supreme Court held that in in the interpretation of the Constitution, it is the duty of this Court which has the ultimate responsibility of declaring and interpreting provisions of the Constitutions always to bear in mind that the Constitution itself is a mechanism under which Laws are to be made by the Legislature and not merely an act which declares what the Law is. Accordingly, where the question is whether the Constitution has used an expression in the wider or in the narrower sense the Court should always lean where the justice of the base so demands, to the broader interpretation unless there is something in the content or in the rest of the Constitution to indicate that the narrower interpretation will best carry out its object and purpose 35 .

In this spirit, it would be seen that the conservative attitude demonstrated towards the offence of sedition in D.P.P. v. Chike Obi, 36 took a dramatic tum by the judgement of the Federal Court of Appeal in Chief Arthur Nwankwo v. The State 37 where it was specifically held that Sections 50 and 51 of the Criminal Code are inconsistent with Sections 36 and 41 of the 1979 Constitution and, to that extent, the sedition laws are null and void. Similarly, in Tony Momoh v. Senate of the National Assembly \& others 38 the Court held that the Senate could not compel a newspaper editor to disclose his source of information as that would interfere with his freedom of expression under the Constitution. Furthermore, a wide and liberal interpretation was given to Sections 36 and 37 of the Constitution in Okogie v. Attorney-General of Lagos State 39 where the trial judge did not hesitate to hold that the 'medium' includes any school or institution for imparting information, ideas, knowledge and opinion. Consequently, if the abolition of private primary schools is implemented, it would affect the right of expression and association.

An interesting case on freedom of movement is Shugaba v. Federal Minister of Internal Affairs 40 . The applicant who had been deported under the pretence that he was not a Nigerian, sued the Minister of Internal Affairs for the violation of his right under Section 38 of the Constitution. It was held that he was entitled to damages for unlawful deportation.

35 Nafiu Rabiu v. State, (1981) 2 NCLR 243; (1980) 8-11 S.C. 130. This view has since been approved by later authorities, e.g. Egaji Ujoh v. The Attomey-General of Benue State, (1982) 3 NCLR 330; Major Adeyemi Ladejobi v. Attomey-General of the Federation, (1982) 3 NCLR 563 at 604; Obekpa v. C.O.P., (1980) 1 NCLR 113 at 118; Ariori v. Elemo, (1983) 1 S.C. NLR 1 (per Eso JSC).

37 Unreported FCA/E/111/83 of $27 / 7 / 83$.

38 (1981) 1 NCLR 21.

39 (1981) 2 NCLR.

40 (1981) 1 NCLR 25. 
The Court was also of the opinion that the seizure of a passport from a Nigerian citizen could amount to infractions of his fundamental rights.

The Constitutional rights to personal liberty and fair hearing were equally given the pride of place. In ONU Obekpa v. C.O.P41, bail for non-capital offences was held to be a Constitutional right and in Bello v. The State 42 failure to assign defence counsel to an accused charged with a capital offence vitiated the trial as the Court held that to be a denial of fair hearing. 43

The case of Adewale \& Ors v. Jakande \& Ors. 44 had to consider almost the whole gamut of fundamental rights in deciding whether the proposed abolition or takeover of private primary schools by the Lagos State Govemment was constitutional. The Court held that the proposed action of Govemment was an infringement of Sections 32, 26, 37, 38, 39 and 40 of the Constitution. Omololu Thomas J. concluded in that case that, having regard to the language used in the provisions and the fact that the Constitution was influenced by the United Nations Universal Declaration of Human Rights, the provisions were to be generously interpreted to give effect to the fundamental rights and freedom contained in the document.

Finally, on the question of locus standi the Courts moved from their pre-1979 restrictive attitude to a liberal conception in Senator Adesanya v. President, Federal Republic of Nigeria45 and indeed to a much wider interpretation in Fawehinmi vs. Akilu \& Togun46.

\section{The Military Interventions}

Since independence, Nigeria has had more in terms of Military administration as opposed to civil rule. Between 1966 and 1976, it had four successive Military regimes, the one headed by General Yakubu Gowon being the only fairly long of the rulership. After a short civilian interregnum under President Shehu Shagari between 1979-1983, it took on another

41 (1981) 2 NCLR 420.

42 (1981) 1 NCLR 677.

43 Ironically, there have been an unnecessary number of alleged violations of fair hearing in spite of the elaborate provisions of Section 33 of the Constitution. See e.g. Augustine Eda v. C.O.P., (1982) 3 NCLR 214; Oyegbemi \& ors v. The Attorney-General of the Federation \& ors, (1982) 3 NCLR 895; Udodima v. C.O.P., (1982) 3 N.C.L.R. 325; Adebayo v. Concord Press Nigeria Ltd., (1982) 3 NCLR 434.

44 (1981) 1 NCLR 262.

45 (1981) 2 NCLR 358.

46 (1987) 4 NWLR 797. 
era of Military intervention under Buhari/Idiagbon and from then till present day a continuation of Military rule under President Ibrahim Babangida.

Expectedly, the Military has its own socio-political characteristics in contrast with civilian administration; furthermore, Military regimes inter se have their own peculiarities and missions to be fulfilled. Clearly, it is only within this context that one can fully appreciate the dimensions of the problem posed by the Military intervention in the Nigerian policy to human rights. Incidentally, while some of the general characteristics of military regimes run through, the Buhari/Idiagbon and the Babangida regime provide a picture of the possibility of divergence of perhaps ambivalence of military attitude to human rights.

Customarily, Military take-overs in Nigeria are legalized, sanctified and ratified by what is now known as the Constitution (Suspension and Modification) Decrees. This came into the history of law-making in Nigeria at the inception of military rule in 1966 when the then military regime passed the ever first Constitution (Suspension and Modification) Decree No. 1 of 1966.

Yet, the initial reaction of the Courts to the Military situation presents a confused judicial picture of the nature of the military administration. While some cases were decided as if the Military administration was a continuation of the old civilian regime, 47 others emphatically denied any change in the legal order (grundnorm) of the nation 48 . However, other decisions, while recognizing the implication of the military situation, by accepting the unlimited legislative powers of the military regime, insisted that the military administration and its agencies must act according to the Law of the Land. 49

A very momentous, if not the most important, constitutional case in this regard is the case of E.O. Lakanmi \& Kikelomo Ola v. The Attorney-General (Westem State) \& Ors50. It was the first occasion on which the highest Court of the land was given the opportunity of determining the real nature of the Military regime, that is whether the regime was a product of a coup d'état or whether it was a continuation of the old civilian govemment which ceased to function, through military intervention on 15 January 196651 . The occasion for this was the validity of the forfeiture of Assets, etc. (Validation) Decree52 of the Federal Military Government by which the assets of the appellants were confiscated. The appellants

47 State v. Nwogu \& Okoye, Suit No. E/342/66.

48 Jackson v. Gowan \& Ors, NBJ, Vol. 8 (1967), p. 87.

49 The Westem State Court of Appeal in Lakanmi \& Anor v. Attomey-General of the Westem State \& Ors, LAW/35/68; Ogunlesi \& Ors v. Attomey-General of the Federation, (1967) NMLR 163, decided on 5th December 1966. See gen. Ojo, Abiola, op. cit., pp. 92-94.

50 SC 58/69 (Unreported).

51 Ojo, Abiola, op. cit., p. 97.

52 No. 45 of 1966. 
contended that their assets had been wrongly confiscated under Decree No. 45 which was invalid and ultra vires the Constitution of the Federation of 1963 because (a) the Federal Military Government was only an interim Military Govemment, to which power had been transferred by the old civilian regime only for a limited purpose should be handed back to them; (b) that the Federal Military Government could only make laws going beyond that purpose if such laws could be justified under the 'doctrine of necessity' and (c) the Decree No. 45 was a legislative act which constituted an unjustified intrusion into the sphere of the judiciary.

Curiously, the Supreme Court unanimously upheld these contentions. 53 Expectedly the Federal Military Govemment promptly re-affirmed the validity of its Legal Order by promulgating the Federal Military Government (Supremacy and Enforcement of Power) Decree.54 It must be observed that the Nigerian Judiciary has not faced any such serious challenge of the legal order since the affirmation of such supremacy by the military govemment.

The guns and the seemingly favourable public sentiments apart, armed with a renewed legal validity and legislative absolutism the emergence of military administration brought one Decree after the other ousting the jurisdiction of the Court for things done or purported to be done. Between January 1966 and September 1979 and between January 1984 and May 1985 there had been some 64 Decrees with conferred unquestionability on executive acts done or purported to be done under their provisions. The first military administration enacted about 45 Decrees with ouster clauses. Furthermore, of the 627 Decrees enacted between 16 January, 1966 and 28 September, 1979, 245 or nearly 50 per cent had retrospective effect, with 52 creating Criminal Offences. 27 or the 49 or 55 per cent of the Decrees enacted between January 1, 1984 and May 15, 1985 have retrospective effect with 11 or 22,5 per cent creating Criminal Offences. The period of retroactivity was mostly less than a year, but in many cases it was more than a year, 8 years being the longest, followed by $61 / 2$ and 5 years. 55

One of the most common and consistent assaults by our military regimes on the rule of law and human rights is the enactment of State Security (Detention of Persons) Decrees, usually at the earliest opportunity of assumption of power. This pattem was re-echoed during the Buhari administration and was adopted and modified by the Babangida regime.56 The Decree empowers the Chief of General Staff or the Inspector General of Police to detain at

53 For a brilliant critic of the decision, see Ojo, Abiola, 'The search for a Grundnorm in Nigeria - The Lakanmi's Case, International and Comparative Law Quarterly, January 1971, pp. 117-36.

54 No. 28 of 1970.

55 Nwabueze, B.O., 'Equality Before the Law', op. cit., pp. 44 and 58.

56 Decree No. 21984. 
will any person for acts prejudicial to state security, and such cases were subject to review every six months from the date of the order. As it is customary, in such decrees section 4(1) of the Decree dictates an ouster clause and bars all legal proceedings for anything done or purported to be done in pursuance of the Decree.

During the early military regimes, the Courts devised their own system to avoid the unpleasantness of such decrees and insisted on strict procedural requirements for the enforcement of such Decree in favour of the Common Law rules of Habeas Corpus. 57 In recent times, it would appear that the Nigerian Courts are now generally getting used to the patterns and ambitions of the military regimes and for good or ill this has led to unnoticeable challenges of the provisions of such enactments 58. It seems that the Courts have understandably but somewhat narrowly maintained the Supremacy of the Constitution as amended by fundamental military decrees. 59

This unbridled legal positivism is in contrast with the approach in other jurisdictions, especially in the United States of America where the Courts have consistently held that the rights of the individual are not derived from governmental agencies either municipal, state or federal or even from the Constitution. They exist inherently in man by endowment of the creator, and are merely reaffirmed in the Constitution, and restricted only to the extent that they have been voluntarily surrendered by the citizenship to the agencies of government. 60

The capriciousness of the Buhari/Idiagbon administration led to the detention of over 700 citizens from various parts of the country under the Decree61. It goes without saying that

57 See e.g. Mojeed Agbaje v. C.O.P., Ibadan Suit No. M/22/69 (Unreported); Chief Nwanji v. Director of Prisons, Suit No. E/11M/69 of 13/6/69; Ishola Rasaq. V. I.G.P., OCHCJ/1975 Lagos High Court; Cecil v. I.G.P., Suit No. M/180/78 of 23/11/78; Segun Okeowo v. I.G.P., Suit No. M/70/78 or 13/6/78; Ekanem v. I.G.P., Suit No. M/1 1/1979 of 16/3/79; Ganiya Olugbemi v. I.G.P., Suit No. M/236/78 of $2 / 4 / 78$.

58 This conclusion is supported by the decision of the Federal Court of Appeal in Wang Ching Tao \& Ors v. Chief of Staff Supreme Headquarters \& Ors., (unreported). 1985 CA/L/25/85, where it held that the refusal of the Lagos High Court to grant an order of Habeas Corpus against the Respondent was correct because Section 4(2) of the State Security (Detention of Persons) Decree No. 2 of 1984, under which the respondent acted precluded the High Court from entertaining such an action and the appellant's Suit was a colourable device to challenge the validity of the Decree. Ademola $J . A$., then concluded that "the combined effect of the provisions of Decrees 2 and 13 is that on the question of Civil Liberties, the Law Courts in Nigeria must as of now blow muted trumpets", pp. 22-23.

59 See e.g. Military Govemor of Ondo State v. Adewunmi, (1988) 3 NWLR 2801988 I (NSCC) 1136 - where the Supreme Court held that the Nigerian Grundnorm lies in the Constitution of the Federal Republic of Nigeria as amended by specific Military Decrees.

60 .See e.g. Dallas v. Mitchell 16 Corpus Juris Secundum, see p. 199.

61 Schedule 1 tothe Review Tribunalis (Implementation of Decisions) Decree No. 25 of 1986 alone contained 714 cases reviewed in the early months of the Babangida regime. 
for some, not for good reasons and in some cases for totally unjustifiable motives. ${ }^{62}$ It might be of interest to note that this was one of the excuses that brought the Babangida administration into power.63 The Babangida regime released most of the detained citizens either conditionally or unconditionally pending formal trials or reviews and ratification of pending cases.64 Obviously with this action the Babangida administration went well in the eyes of the public as the great protector of human rights. To some, however, that may sound like cosmetic lip-service as the same administration, rather than repeal the state security (Detention of Persons) Decree, only came out with a more potent amendment Decree in 1986.65

Furthermore, on assumption of office by Babangida some members of the former administration were detained without charge66, and in December dozens of other people were arrested after the alleged discovery of a conspiracy against Babangida's govemment 67 . These, apart recent events have compelled the Nigerian public to be more wary about the posture of the Babangida administration as a respecter of human rights. For example, Chief Gani Fawehinmi, a famous lawyer and a great crusader against the violations of human rights was detained without any good reasons under the State Security Decree between the months of July and September 1989 and, to the bargain, thoroughly and exceptionally maltreated. The flimsy excuse on the part of government was that he addressed or purports to address a press conference on alternatives to the country's economic structural adjustment programme. He was eventually released after a lot of public outcries, appeals and indeed demonstrations by students in some parts of the country. Even his release was followed by vigorous campaigns on the state of human rights and in particular a call for the State Security Decree.68 Not surprisingly, perhaps true to form, the Babangida administration

62 Some of the cases contested in Courts are Tai Solarin \& ors v. I.G.P., (unreported) M/55/84; Munwell Okudoh v. C.O.P., Lagos State M/32/84; Lamina Arowoye \& ors v. I.G.P., ID/4M/84.

63 This could be gathered from the post-coup broadcast of General Babangida on August 27, 1984.

64 This is consequent on the provisions of the Review Tribunals (Implementation of Decisions) Decree No. 25 of 1986.

65 State Security (Detention of Persons) (Amendment) Decree No. 12 of 1986. Hitherto, the Chief of Staff, Supreme Headquarters, shall, not later than three months thereafter, review the case of a person detained pursuant to the order, the new decree now substituted 'six months' for the 'three months' in the exercice of the power now vested in either the Chief of General Staff or the Inspector-General of the decree would spend a longer time in detention before his case comes up for review.

66 These then included the former Head of State and his Deputy-Major-General Muhammed Buhari and Major-General Tunde Idiagbon.

67 Amnesty International Report 1986, London, p. 76.

68 Other instances which deserve mention are the proscription of the Academic Staff Union of Nigerian Universities in the wake of students' unrest in some of the University Campuses in 1988; the proscription of the Nigerian Labour Congress after an aborted election of officers at its annual Conference 1987. In both cases, officials of the proscribed associations were detaines for questioning for varying periods of time. Also very recently, the Newswatch, a weekly magazine, was 
came out in the early week of November 1989 with an instruction to the Federal AttorneyGeneral to set up a Review Committee on the state of human rights in the country. This gesture was expected from a politically conscious government but which cannot always avoid a military pattern of behaviour in unpleasant circumstances. Extending the frontiers of this, we might be led into a general military sensitivity on the question of freedom of expression.

The traditional checks and balance to freedom of expression in Nigeria are the laws of defamation, sedition69 and the Official Secrets Act of 1962. In 1976 the then military regime headed by General Olusegun Obasanjo passed the Public officers (Protection Against False Accusation) Decree No. 11 of 1976. The Decree was repealed but substantially re-enacted by the Buhari Administration as Decree No. 4 of 1984. In essence, the Decree made it an offence for any of the print of electronic media to print or transmit without justification any false message, rumour, report or statement calculated to bring to ridicule or disrepute the Federal or any State Govemments or any public officer, as defined in the Decree. Persons convicted for an offence under the Decree were liable to imprisonment for a term not exceeding two years without the option of a fine. The adjudicating authority under the 1984 Decree was a special military tribunal - as indeed in most of the military decrees. The expression of public oddity and/or resistance to this Decree came to a climax with one trial of two of the senior joumalists in the Guardian Newspaper - Tunde Thompson and Nduka Trabor70 - for publishing three different items which touched on Nigerian foreign policy, in particular changes in the diplomatic postings of the Federal Govemment of Nigeria. The two joumalists were found guilty of the offence of publishing false statements under Section 1 (1) of the Public Officers (Protection Against False Accusation) Decree No. 4 of 1984 and were accordingly sentenced to a mandatory two-year term of imprisonment before the Ayinde Tribunal in June 1984. After this stage, it became obvious that the Press was bent on exposing the weaknesses of the Buhari Administration in relation to press freedom in particular and to human rights in general. Furthermore, members of the public got disenchanted with the Buhari Administration, and any vigilant observer of the dynamics of public opinion could read through the lines that the end was near for the Buhari Regime. Indeed it is probably not too much out of place to say that the trial and conviction of the journalists under Decree 4 of 1984 was the last straw that broke the back of the Buhari Administration. It goes without saying that Decree No. 4 of 1984 was a direct onslaught on the hitherto welcomed and cherished press freedom. Perhaps, this

banned for publishing the report of the Constitution Review Committee which was allegedly under 'Confidential' cover of Govemment. Indeed, the Editor and some senior members of staff were detained and interrogared. The order banning the publication of the magazine was lifted after six months (see Akande, Jadesola, op. cit., pp. 112-113).

69 As contained in Sections 50 and 51 of the Criminal Code.

70 For the judgement of the Ayinde Tribunal, see The Guardian, Vol. 2 No. 385 (Friday, July 6, 1984). 
explains the determined resistance of the press to any limitation, suppression or the total removal of their constitutional guarantee.

Not surprisingly, therefore, the first thing that the Babangida Regime did on assuming power was the repeal of Decree No. 4 of 1984. This was consequent on a post-coup broadcast by General Babangida on August 27, 1984, followed by formal ratification by the Armed Forces Ruling Council on October 31, 1985 and then the Public Officers (Protection Against False Accusation) Repeal Decree No. 20 of 1985. From then on, it would appear that the Babangida Administration was bent on the maintenance of press freedom at least within the limits permitted by the Constitution. Development in recent times, however, might suggest that not even the Babangida Administration is far removed from the occasional oversensitivity on news items that characterised some of the previous military regimes. Recently, the Newswatch Magazine was banned and its premises sealed up for an attempt to circulate its weekly magazine which contained certain classified and confidential information conceming the report of the Federal Government constituted political bureau, headed by Dr. J. S. Cookey. The ban and the sealing up of the premises of the Newswatch magazine first came by way of a declaratory announcement and later followed up by the Newswatch (Proscription and Prohibition from Circulation) Decree No. 6 of 1987.

The Decree proscribes and prohibits from circulation in Nigeria or any part thereof the weekly news magazine known as Newswatch for a period of six months from the commencement of the Decree unless further extended by the appropriate authority by an order in the Gazette. Generally, the Decree seems to find some expression and/or justification in the constitutional provisions relating to laws that are reasonably justifiable in a democratic society in the interest of defence, public safety, public order, and public morality. ${ }^{71}$

Parodoxically, even with the emergence of the rather offensive Newswatch prohibition Decree No. 6 of 1987, President Babangida maintained consistently that there would never be any legislation similar to Decree No. 4 of 1984 during his tenure. This might suggest that Decree No. 6 of 1987 is merely an isolated deterrent legislation, but taken together with events in recent times the human rights posture of the Babangida administration seems to have been fairly dented.

As with the freedom of expression, a similar military consistency is noticeable with reason offences. The Obasanjo regime again went outside the provisions of the Criminal Code and promulgated the Treason and other Offences (Special Military Tribunal) Decree No. 8 of

71 The Decree started with a preamble which reiterated the limits to constitutional freedom of expression as contained in S 41 of the Constitution. It reads inter alia, "And whereas it is necessary to take appropriate measures to prevent further disclosure of classified and confidential matters in the interest of public safety and public order." 
1976 and constituted a Special Military Tribunal for the trial of any person whether or not a member of the armed forces who in connection with the rebellion of 13th February, 1976 committed the offence of treason, murder or any offence under any law in Nigeria. For almost a decade, from Obasanjo to Babangida, no attention was paid to the enactment because there was no unsuccessful coup d'état within this period. However, in 1986, the Babangida administration repealed and re-enacted the Treason and other Offences (Special Military Tribunal) Decree No. 2 of 1986 which is further amended by Decree No. 3 of 1986. As in the 1976 Decree, the Decree empowers the Armed Forces Ruling Council to constitute a Special Military Tribunal for the trial of any person, whether or not a member of the armed forces who in connection with any rebellion against the Federal Military Govemment has committed the offence of treason, murder or any offence under any law in Nigeria. In the Celebrated Case of State v. Major General Mamman Vatsa \& 16 ors, 72 an essentially military procedure was adopted in the trial. Furthermore, the sittings of the tribunal were held behind closed doors, neither were the accused persons given the opportunity of having counsel of their choice. Rather, they had military advocates to present their cases to the tribunal and to crown the violation $s$ of procedural human rights, a right of appeal only lay to the Joint Chief of Staff Committee, equally a military body that would make final recommendations to the Armed Forces Ruling Council.

\section{From Buhari to Babangida}

The incessant corruption and gross abuse of office that characterised the Nigerian Second Republic under the Presidency of Alhaji Shehu Shagari created a glaring welcome reception of the military coup which led to the birth of the Buhari regime in December 1983.

The circumstances provided sufficient moral justification for the entire military posture and toughness of the Buhari/Idiagbon regime, which led at least for some time to acceptable violations of human rights and procedures. The culmination of this was the enactment of 53 Decrees out of which 26 had retrospective effect 73 Not surprisingly, however, their perception of rule of law was the product of their mission; they therefore favoured a definiton of crime and the criminal law process which recklessly disregarded fundamental human rights

72 Unreported decision of the Special Military Panel on Treason-throughly discussed by Ughovwa, S.O., "The Scope of the Law of Treason in Nigerian Law", unpublished LL.M. Dissertation Obafemi Awolowo University, Ile-Ife 1986.

73 See e.g. Agbede, I.O., "Law and Social Justice: Nigerian Experience, being the text of the Annual Lecture of the Post-Graduate School, Obafemi Awolowo University, Ile-Ife, delivered on June 2, 1987. 
and found expression in the array of draconian decrees passed in the short rule ${ }^{74}$. This peculiar outfit of the Buhari administration must have led Nwabueze to conclude that 75 :

"A military government is the product of a revolution inspired by a certain mission. That mission is predetermined by the circumstances and conditions that prompted it to take over the government. As so determined, the mission of a military govemment in Nigeria can be easily stated: to repair the ravages of political warfare between opposing political parties, to rehabilitate the economy from the damage of mismanagement by the civilian rulers, to ameliorate the depressing conditions of life resulting from government neglect and lack of concem for the welfare of the people, to punish the unbridled corruption of tha past and check its future occurrence, to recover public money and property lost through corruption, and generally to cleanse the society of the scourges of corruption, abuse of of fice and indiscipline, and thereby to forge a national habit of orderly and disciplined social life, a national ethic of patriotism and respect for the national interest of obedience to the laws, of service to the nation and of self-reliance."76

It goes without saying that one of the reasons for the warm reception of the Babangida administration was the excesses of the Buhari/Idiagbon regime. Necessarily therefore, the Babangida regime had to create room for the conflicts generated by the Buhari rule in order to maintain its own political stability for the attainment of socio-economic successes. Not surprisingly, the Babangida government de-emphasised militarism in favour of a reasonably acceptable human rights posture. 77 However, even within that attempt or perhaps lipservice to a meaningful policy on human rights, the totality of our military experience still gives room for valid generalisations as to the nature and characteristics of military decrees.

74 Some of such important specitic enactments are the State Security (Detention of Persons) Decree, Recovery of Public Property (Special Military Tribunals) Decree, The Special Tribunal (Miscellaneous Offences) Decree, Exchange Control (Anti-Sabotage) and the Counterfeit Currency (Special Provisions) Decrees, Treason and other Offences (Special Military Tribunal) Decree, Public Officers (Protection Against False Accusation) Decree and the Transition to Civil Rule (Political Programme) Decree. See gen. Owoade, M.A., "Human Rights and the Criminal Justice System in Nigeria - from Buhari to Babangida", 9 HRLJ (1988), pp. 181-203.

75 Nwabueze, B.O., "The process and challenges of Legislation in a Military Govemment", The Nigerian Bar Journal, Vol. XVIII No. 1 (1984), p. 73.

76 More recently the same author opined that "while the legislative absolutism and supremacy of the military govemment must be accepted as an inevitable and incontrovertible consequence of the overthrow of a country's Constitution in a military coup, orderly and disciplined administration of govemment demands that executive acts of the military govemment which are not in conformity with its own laws should be open to challenge in the Courts", "Equality Before the Law", op. cit., p. 46.

77 Owoade, M.A., op. cit., p. 203. 
First, there is a tendency to military despatch in their legislation. The dangers in hurried and panicky legislation are that they are inconsistent, often quickly replaced by another set of rules, sometimes unfair and on the whole create a crisis of confidence in the system of administration. Secondly, they often contain ouster clauses preventing the Courts from looking into the purport of such enactments. This not only creates problem of the scope and/or delimitation of powers of the Courts, but also attracts the imputation of bad motives on government actions. The third is retroactiveness. Obviously, this is a negation of the principle of legality and consequently the rule of law. Fourthly, military decrees impose fundamental changes on the rules of evidence such as those relating to presumption of innocence, burden of proof, competence and the admissibility of accomplice's evidence. Fifthly, almost invariably, the enactments dictate long and usually mandatory sentences, with a statutory minimum, if not death sentence.

\section{Conclusion}

Though Nigeria has played an important role in formulating the African Charter of human rights and bringing it into force and has acceded to many treaties since the respect for human rights is now a customary obligation in international law, 78 nevertheless, this paper does not concern itself with the international law dimensions of human rights. Rather it focusses on the development processes of human rights within the framework of Constitutional history and the Nigerian socio-legal order. It accepts a wide definition of human rights and/or fundamental rights in the context of the doctrine of natural rights and the philosophy of natural law, which have provided the conception of man in a social order and the key to the values of human dignity and respect for man's inherent and inalienable rights in a legal system. Clearly, the present state of civilisation prescribes that governments are obliged to respect certain minimum obligations and as far as Nigeria is concerned, the resourcefulness of human rights has gone beyond the myopic imagination of the 'founding fathers' who were motivated by the need for the protection of minorities 79 . The dichoto-

78 Umozurike, $O$., "Extending the frontiers of human rights", The Guardian, Saturday, November 11, 1989,p. 9.

79 Constitutional guarantee of human rights adapted in Nigeria in 1959. Cornmentators agree that this was due to the recommendations of the Willink Commission of Minorities - see e.g. Ezejiofor, G., Protection of Human Rights under Law, London 1964, pp. 178-183; de Smith, S.A., The New Commonwealth and its Constitutions, London 1964, pp. 177-179. The Commission, whilst not agreeing to the demands made by certain parties that more regions should be created to protect the interest of minorities, and whilst not itself believing in the efficacy of constitutional guarantees of freedom in the Constitution hoped that their inclusion would be of great value in preventing a steady deterioration in standards of freedoms and the unobstructive encroachment of a government on individual rights (Park, A., "The independence Constitution of Nigeria in Retrospect", Collected Seminar Papers, University of London, Institute of Commonwealth Studies, No. 5 (1968), pp. 5861. 
mized historical development permits a broad division into civil and military rule. With the former, at least in the arena of political and civil rights, the country seemed to have faired well with the assistance of an increasingly bold judiciary. However, a period of Constitutional anomie was created by the inherently destabilising influence of the military in power. 80 This created such fundamental questions as the relationship between human rights as ideals and the possible tolerance of breaches by the citizenry for sometimes equally important ideals, indeed with such holistic connection as political/civil rights versus socioeconomic rights. This is more so as the usual excuse of the military in power is the protection of the so called second generation rights 81 of socio-economic rights.

The unresolved ideological question is how to balance the possible contradictions posed within a given socio-political milieu in the implementation of the different categories of human rights. Nevertheless, and perhaps ironically, the Nigerian military did not fair well in the achievement of socio-economic rights and unlike the civilian administrations, neither did it succeed in the respect for political and civil rights. More generally, given the past experience of African states and current economic and political development on the continent, we do not see a bright future for the promotion and protection of human rights in African States. 82

80 To use the words of Dr. Olu Onagoruwa in "All equal before the Law", Nigerian Tribune, 28th December, 1987 - as published in Fawehinmi, Gani, Murder of Dele Giwa - The Right of A Private Prosecutor, 1988, p. 158.

81 See e.g. Umozurike, $O$., "Extending the frontiers of human rights", op. cit., p. 9.

82 Ojo, O. and Sesay, A., "The O.A.U. and Human Rights, Prospects for the 1980s and Beyond", Human Rights Quarterly, Vol. 8, No. 1 (February 1986), p. 101. 


\section{Human Rights as a Resource - The Nigerian Experience}

\section{By M. Adekunle Owoade}

Rather than focussing on the international law dimensions of human rights with respect to Nigeria, the article turns to the development processes of human rights within the framework of constitutional history and the Nigerian socio-legal order. The legal developments in Nigeria are discussed on the basis of a wide definition of human and fundamental rights and in the context of the doctrine of natural rights and the philosophy of natural law.

Under both the military and the civil govemment the socio-legal development in Nigeria was characterized by the conflict between the guarantee of civil rights and the need for action with respec to the implementation of social and economic rights. In more general terms, this conflict does not promise a bright future for the promotion and protection of human rights in African states in the light of their past experiences.

The Effect of Modernization on Acquisition of Property and the Rules of Compensation - A Kenyan Case

\section{By R. S. Bhalla}

The constitution of Kenya provides that the state can impose restrictions on the enjoyment and use of property in certain circumstances. If necessary in the wider interest of the community, it can even deprive a person of his private property paying him compensation.

This article is restricted to this aspect of compensation. It examines the rules relating to compensation as provided for by the Land Acquisition Act, Cap. 295. Market value, as a basis for compensation, is only partially effective in restoring the owner's financial position. The main stress in this essay is on the need to compensate the individual to the nearest point of his self-satisfaction. 